\title{
The role of financial analysis in evaluating the performance of industrial enterprises to predict financial failure
}

\begin{abstract}
:
This study aimed to describe the effects of the financial analysis to predict the financial failure of enterprises through using of financial ratios. Also to build a model consisting of a set of financial ratios through of their weight. It reflects the extent of its importance in predicting the failure of industrial enterprises and success. This can take appropriate action to avoid financial failure before it happens. The main results of the study, reaching is four financial ratios explain and predict financial performance individually. These are a ratio of current assets to total assets, ratio of debtors to sales, ratio of net profit before interest and tax to current liabilities, and ratio of the market value of capital-to-book value of the total debt. The last one was the most important ratio. The model consists of three financial ratios are the strongest influence through statistical analysis of financial ratios. This model was able to re-rating of food enterprises successful and failed fully and accurately by (100\%). It was able to distinguish between successful enterprises and failed in another sample from the same sector by (90\%) and therefore, the accuracy of this model is very high, and reliable.

The model showed that it does not need many financial ratios to be able to predict the failure of the financial performance of enterprises. That with the advancement of statistical analysis methods remains discriminatory analysis statistical tool is very effective, and reliable.
\end{abstract}

Keywords: Financial analysis, performance evaluation, prediction of financial failure.

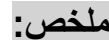

هدفت الدراسة إلى بيان أثر التحليل المالي في التنبؤ بالتعثر المالي للمنشأة من خلال التهال

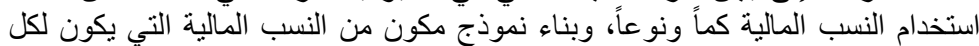

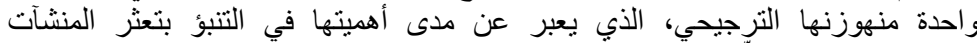

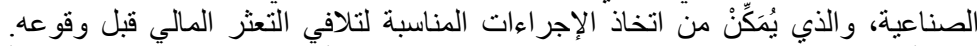

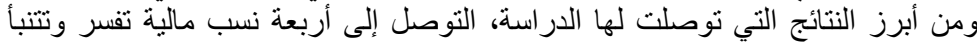

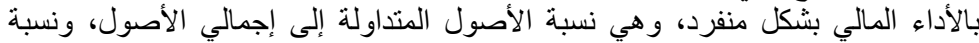

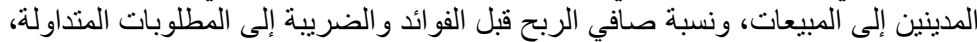

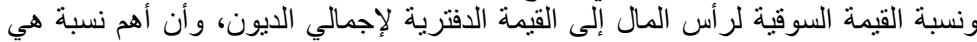

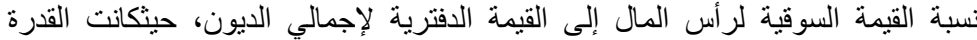

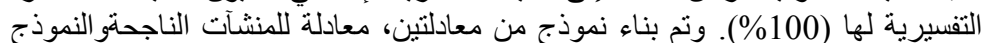

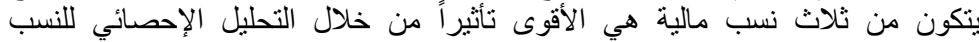

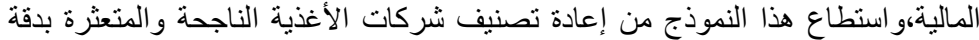

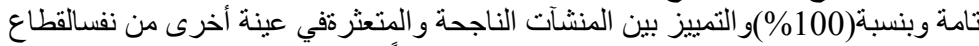

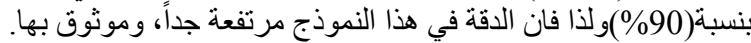

\author{
Dr. Talal A. AL- Kassar ${ }^{(1)}$ \\ Dr. Mourad Kouachi (2)
}

Ammar Nasruldeen Mohammed Sheet ${ }^{(1)}$

${ }^{1}$ Department of Accounting Faculty of EconomicsandAdministr Zarqa University Jordan

${ }^{2}$ Faculty of Economics Management and Business Sciences University of Oum EI Bouaghi Algeria

\section{Introduction :}

The industrial sector is the most important component sectors of the Jordanian economy. It contributes about a quarter of GDP directly. In addition to its association with many of the other economic sectors, and absorbs part of the labor force of Jordan. It provides opportunities for rehabilitation and training them. Which up gradation of technical and increase productivity. 
Therefore, the estimated labor engaged in it about (15\%) of the total workforce. It contributes to cover part of the deficit of the trade balance through exports. This constitutes an important part of the total exports with estimated industrial exports about $90 \%$ of the total merchandise exports. It seeks all countries of the world to promote this sector to contribute effectively to the achievement of economic development through the success of the industrial sector enterprises. In addition, strive to not stumble, and work on the sustainability of its success by providing all economic requirements and the face of crises before they occur so that, it can be measured and predicted. (http://www.jci.org.jo).

In Jordan, industrial sector suffered of the conditions of financial and technical, as can identified. Many of them have stopped and some of them have privatized. Thus, it requires identifying the factors that contributed to the deterioration of the financial conditions. These might be resulted of financial distress for some of them, and perhaps collapse the future for others.

The need for indicators and analyzes appropriate contribute to the provision of accounting information suitable for various activities. This is through the expression of the strength or weakness of its financial performance in order to distinguish between these enterprises and the future direction of predictability.

The financial ratios of the most famous tools for economic unity, and used by analysts to determine whether they were advised to lend economic union or not, and performance monitoring and evaluation (Accounting Program of Egyptian Banks and the Stock Exchanges, (http://bu.edu.eg) p: 193).

Financial analysis has been used traditionally for the purposes of credit and investment, and spread the use of financial analysis for the newly up to the goals of administrative, financial analytical approach helps mainly in process control, and performance evaluation, financial planning and other administrative functions. Thus, in the field of control and performance management can use financial analysis to answer many questions they face. Which is in the process of decision-making routine and non-routine, and these questions:

- What is extent the success of the management of the enterprise to achieve an appropriate return on the resources available to them?

- Is it the best performance of the enterprise, or less than their counterparts - Is in the same industry?

Thus, helps to make the process of financial analysis to make informed decisions in the field of control and performance evaluation is possible and affordable. (Khalayla, 2012).

Despite the copious number of statistical failure prediction models described in the literature, testing of whether such methodologies work in practice are lacking. There are emerged several trends towards the use of statistical methods in evaluating the performance of enterprises, predict this performance in the future, and provided many of the studies that aimed to use statistical models for 
forecasting purposes a stalled enterprise performance. There were a large number of models to predict the performance of businesses. These models in composition financial ratios extracted from the financial reports for those enterprises. The researchers have begun as previous studies ended in this area, which has centered in the following directions:

1 - a trend that focuses on the use of the best financial ratios in predicting a failure companies, and that after they are analyzed and tested in the most accurate prediction, and represents the trend (Beaver, 1966).

2 - a trend that aims to better financial ratios in the form of a model that can predict the failure of companies using multiple linear analysis of the discriminatory variables, and represents the trend (Altman, 1968).

Therefore, this study used statistical methods, especially the method of analysis, multivariate linear discriminatory in the development of style financial ratios by building a quantitative model consisting of a set of financial ratios used indicator to distinguish and predict financial performance of industrial plants.

Although the disclosure and laws governing the enterprises of the industrial sector by the Securities institutions. There are still shortcomings by industrial plants to use the traditional proportions of the financial analysis of the financial statements for the purpose of performance evaluation and prediction of financial failure. This may lead to financial failure according to field study carried out by researcher. The disclosures that must carried out, it was necessary to work on the study of how to predict financial failure. The work on performance evaluation and analysis by building a quantitative model component from a number of financial ratios and the use of appropriate statistical method contributes to the early detection of crisis that may exposed to the enterprise.

Accordingly, the problem of the study lies in the answer to the following two questions:

Q1-What is the ability of financial ratios to predict financial performance of failure enterprises?

Q2- Is the model has the ability to distinguish between industrial enterprises as success or fail?

The study seeks to achieve the following objectives:

1 - The formulation of the intellectual aspects of financial analysis and use it to develop methods to predict financial failure of the enterprises.

2 - To identify the extent of the impact of financial ratios to measure the faltering financial performance of industrial plants.

3 - Develop a model to predict the financial failure of industrial plants, depending on financial ratios.

This study is important from a number of aspects of the following: 
1 - This study presents an analysis and explanation of the financial ratios that affect the measurement of financial performance, and determine the relative importance of each financial ratio. These serve researchers and analysts.

2 - This study provides a control model by the stock exchange for the early detection of faltering financial performance of the industrial installations of Jordan. Then work to improve performance through the issuance of laws and regulations that help to offset the obstacles and solving problems.

3 - The study provides appropriate solutions to identify the trend established towards success, or failing, and seeking to manage the enterprise in manner to overcome the obstacles that limit the performance improvement.

\section{Literature review}

Financial analysis is one of the tools that help in accounting to get different information about the financial statements. It plays an important role in the process of performance evaluation and prediction of businesses successfully or stumbles. The optional pricing model developed by Black and Scholes in 1973 and Merton in 1974 provided the foundation upon which structural credit models have built. KMV (Kealhofer, McQuown and Vasicek), Now Part of Moody's Analytics Enterprise Risk Solutions, was the first to commercialize the structural bankruptcy prediction model in the late 1980s. Miller (2009) noted, "The Distance to Default is not an empirically created model, but rather a mathematical conclusion based on the assumption that a company will default on its financial obligations when its assets are worth less than its liabilities. It is also based on all of the assumptions of the Black-Scholes option pricing model, including for example, that asset returns are log-normally distributed".

Financial performance and financial analysis become one of most important areas in cognitive science. Its need started after the huge collapses and repression of many companies that took place in late twenties and early thirties, which imposed the need to study company's financial reports content effectively to enable the related and concerned of financial statement, know their real performance, and predicting company future. Its importance its increase after Second World War, where inflation phenomenon started to spread and its impact on financial statement. This was the reason of using new quantity means in financial analysis process for raising analysis efficiency to be a tool in decision-making, on either state level or private companies' level. (Khanfar \& Mattarneh, 2011).

The financial analysis is one of the most important topics in the operations of the investment, because of its ability senior assistant in the analysis and interpretation of the results of the financial statements in the financial statements. Also its ability to predict the conduct of knowing the points the strengths and weaknesses of the companies. Where financial analysis convert vast amount of historical figures to organized relationship. It provides 
information that are more benefits to decision-makers, to use for evaluate companies financial and credit positions (Al-Nu'aimi and Al-Tamimi, 2008). Therefore financial analysis is considered as main pillar in provide financial statements that most useful in decision-making process rationalization, and it works on using financial statement and information to find ration and mathematical models that seeking to get information that use in performance evaluation process and good decision-making. Al-Sheikh, (2008), mentioned that financial statements analysis consider as a tool to explain this statement, and identify its content relationship, figures significance that listed in, and provide information that helps on estimate institution value (Al-Khalayla, 2012). Financial analysis show management and board of director's efficiency and capacity to perform duties and work properly, also show company and its department's efficiency extant performance in doing its function and activities.

As a result of economic developments no longer results shown by the financial statements is sufficient for the purposes of investment, financing and decisionmaking various. Therefore, it was necessary to study such data for scrutiny and analysis in order to stand on the fact that the development of the unit and the study of the causes of success and failure. Since the success and progress should not be as a luck or not because of external influences of the unit by any economic status changes and price levels. Therefore, it was necessary for the unit of economic planning activities for the next period and the planning needs of course to control the implementation and evaluation of performance and identify deviations. (Mohammed et al, 2008).

The empirical literature reviewed by Chenhall (2006), for example, indicates that non-financial performance measures are more widely adopted in just in time (JIT) and total quality management (TQM) settings. Other studies like Abdel-Kader and Luther (2008) have highlighted the need for additional research to increase our understanding of organizational and environmental factors that explain the development of management accounting systems, including the use of non-financial measures. Accounting information plays an important role in individual and corporate decision-making. In particular, a fundamental use of accounting information is to help different parties make an effective decision concerning their investment portfolios. Much of the accounting literature assumes that accounting and financial reporting in a country is a function of its environment (Belkaoui and AlNajjar, 2006). The management accounting literature reveals that changes in the environment and the technology of a company can lead to new decision making and control problems (Abdel-Maksoud et al., 2010).

There are many goals and purposes of financial analysis, and methods of mention and display differed between writers, (Khanfar \& Mattarneh (2011). It mentions set of objectives, which know institution financial position, judgment 
of company profitability ability, judgment of financial and operational performance efficiency in the company, internal control restriction and future planning, knowing weakness and strength points in the institution and work to develop solutions, and knowing institution capacity extant to satisfy its debt position in long or short term. Financial analysis is consider as one of most important subject particularly in investments process, because of its capacity in helping in analysis and explain financial data in financial statement, and its capacity of predicting companies operations, and shows company capacity extant in doing its functions and identify its continuity extant, and knowing strength and weakness points in companies.

The sources of financial analysis for better evaluation depend on the following statements:

1 - Balance Sheet.

2 - Income statement.

3 - Cash Flow Statement.

These types of financial ratios have used in our study (see appendix 1) are:

1 - Liquidity ratios

2 - Activity ratios

3 - Solvency ratios

4 - Profitability ratios

5 - Market rates

There were many previous studies in this filed such as (see for instance, Beaver, (1966) Altman (1968), Taffler (1977, 1983 and 2005),Argenti, (1976), De Toni and Tonchia (2001), Mohammed (2005), Bernard et al. (2007), Munuswamy \& Mohamed (2012), Al-Kassar and Soileau (2012) \& (2014),and many others.

The Altman model is as follow:

Altman-Z $=0.0012(\mathrm{WC}) \quad+0.014(\mathrm{RE}) \quad+0.033(\mathrm{EBIT}) \quad+0.006(\mathrm{MVE})$ +0.00999 (NCI)

Where:

Altman-Z is the Z-score or predictive measure of corporate bankruptcy, $\mathrm{WC}$ is the ratio of working capital scaled by total assets,

$\mathrm{RE}$ is the ratio of retained earnings scaled by total assets,

EBIT is the ratio of earnings before interest and taxes scaled by total assets,

MVE is the ratio of market value of equity scaled by the book value of total debt, and

$\mathrm{NCI}$ is the ratio of sales scaled by total assets.

According to Altman (1968), a minimum Altman-Z score of 1.8 is necessary to avoid failure, but only with a $z$-score of 3.0 or more is the 
The role of financial analysis in evaluating the performance of industrial enterprises to predict financial failure

company fairly safe. Using the following modified Z-Score model, Taffler (1983) studied solvency among UK companies:

$\mathrm{Z}-\mathrm{Scr}=\mathrm{C}_{0}+0.053 *(\mathrm{PBT} / \mathrm{CL})+0.13 *(\mathrm{CA} / \mathrm{TL})+0.18 *(\mathrm{CL} / \mathrm{TA})+0.16 *(\mathrm{NCI})$

Where:

Z-Score: Taffler's solvency z-score for UK companies,

$\mathrm{C}_{0}$ : constant,

$\mathrm{PBT} / \mathrm{CL}$ is the ratio of profit before taxes scaled by current liabilities,

$\mathrm{CA} / \mathrm{TL}$ is the ratio of current assets scaled by total liabilities,

$\mathrm{CL} / \mathrm{TA}$ is the ratio of current liabilities scaled by total assets,

NCI ('no credit' interval) is calculated as the difference between the quick assets and current liabilities scaled by the daily operating expenses [(quick assets -current liabilities)/daily operating expenses] as a measure of short-term liquidity. More specifically, the ratio indicates the number of days, which a company can continue to finance operations from its existing quick assets if revenues are cut-off.

Based on the Taffler (1983) model, the coefficient percentages C1 to C4 contribute $0.53,0.13,0.18$, and 0.16 respectively, to the models operation. Companies with a ZT-Score above a certain threshold (i.e. Z-Score $=0$ ) were predicted not fail during the next year.

Financial ratios are considered one to the most financial analysis tools commonly used, and there is no specific list includes all these percents sue anyone who is performing analysis can attribute any number of statement to another number, in the current year to a number inprevious year, if this comparison was meaningful and significant . (Al-Khalayla (2012), p 42)."Financial ratio is a tool of financial analysis tools, provides a measure of relationship between two items of financial statements (Khanfar, Mattarneh, 2011). Al-Nu'aimi and Al-Tamimi, (2008), define it: as a relationship between accounting values listed in the financial statements arranges and organized to be a function for performance evaluation of a particular activity at a particular point time. The financial ratios is a process of financial data available about an institution in order to obtain information used in decision-making process. In addition, in assessing trades and industry institutions performance in the past and present as well as in diagnosis of any problem exist (financial or operational) and anticipating what will be the situation in the future (Karajeh et al, 2006).

\section{Research Methodology}


This study pursues inductive approach in the analysis, which is an approach based on observation and testing. It depends on the data, and the information available about the problem to study.

It has been prepared for the general framework of aspects in the field of financial analysis to predict the level of success of the enterprises or failure, with a focus on the method of analysis, multivariate linear discriminatory.

The present study using financial ratios to predict the success of the industrial enterprises, or stumble. It works to build a quantitative model includes a set of financial ratios that show the fact that the financial situation of enterprises. It can used in evaluating the performance of industrial plants in the industrial sector to help predict the success of these enterprises. Alternatively, stalled before it occurs, which helps management established the possibility of taking the appropriate decisions at the appropriate time to address errors and tripping and the pursuit of success.

\subsection{Hypotheses of the study}

We have been building hypotheses based on the study of the problem of industrial installations sample study to identify performance, and predictability of financial failure, have been formulating hypotheses positive following:

Ho1: There is a positive effect statistically significant at the level of significance $(\alpha \leq 0.05)$ between financial ratios and predict of fail financial performance of industrial enterprises.

This hypothesis can divided to the following sub-hypotheses:

$\mathrm{Ho}_{1} \mathrm{a}$ : There is a positive effect statistically significant at the level of significance $(\alpha \leq 0.05)$ between liquidity ratios predict of fail financial performance of industrial enterprises.

$\mathrm{Ho}_{1} \mathrm{~b}$ : There is a positive effect statistically significant at the level of significance $(\alpha \leq 0.05)$ between activity ratios and predict of fail financial performanceof industrial enterprises.

$\mathrm{Ho}_{1} \mathrm{c}$ : There is a positive effect statistically significant at the level of significance $(\alpha \leq 0.05)$ between the solvency and predict of fail financial performance of industrial enterprises.

$\mathrm{Ho}_{1} \mathrm{~d}$ : There is a positive effect statistically significant at the level of significance $(\alpha \leq 0.05)$ between profitability ratios and predict of fail financial performanceof industrial enterprises.

$\mathrm{Ho}_{1} \mathrm{e}$ : There is a positive effect statistically significant at the level of significance $(\alpha \leq 0.05)$ between market rates and predict of fail financial performanceof industrial enterprises.

$\mathrm{Ho}_{2}$ : Distinguishes quantitative predictive model consisting of a set of financial ratios, which will reached by using the statistical method accurately between successful industrial enterprises and distressed. 


\subsection{Study Model}

The model of the study was to represent a set of independent variables financial ratios, and the dependent variable will be the financial performance of the industrial enterprises of the study sample, and as shown in the following figure:

\section{Authors)}

\section{(Figure 1) Study model (Prepared by}

Independent variables

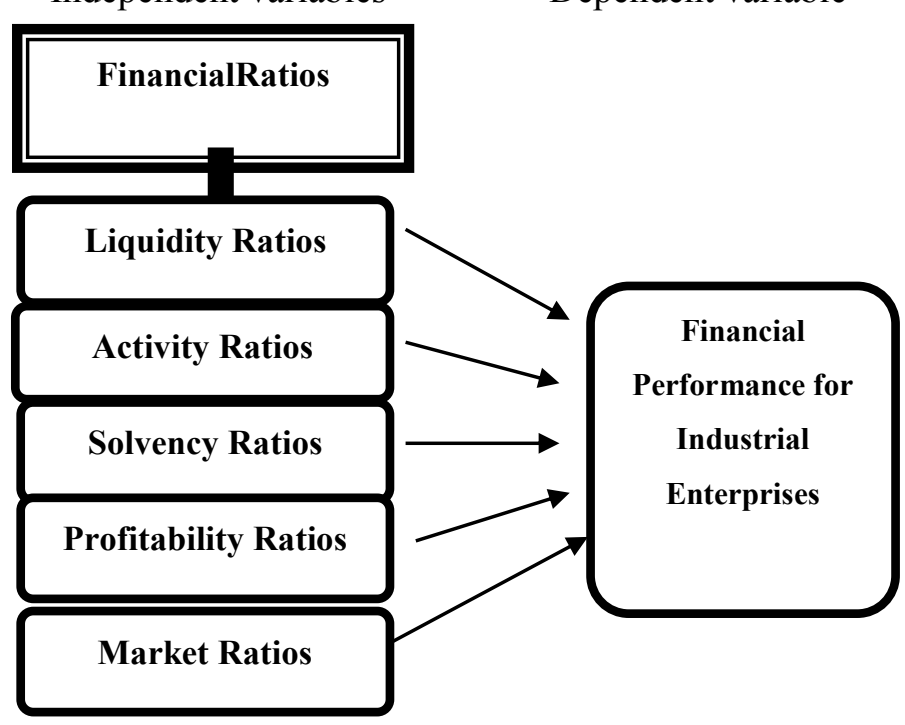

The financial ratios have utilized from previous studies. It focus on the best out financial ratios that work on performance measurement and prediction of financial failure. They have identified (30) financial ratio, divided into five groups: liquidity, activity, solvency, profitability and the market, as shown in Appendix 1.

3.3 The population of the study sample

The study examined a sample of the industrial sector enterprises operating in Jordan. Which applied in the food sector include (12) enterprises that equal to (17.1\%) of the total of the industrial sector (70) Jordanian industrial enterprises.

\subsection{Data collection}

To achieve the purposes of the present study the researchers were adopted two types of sources of data collection, namely:

A - Primary Data 
It is referring to books, theses published, published scientific research, reports and magazines that focused on financial analysis of economic establishments and success.

$B$ - Secondary Data

Researchers adopted the audited financial statements authorized by industrial enterprises such as balance sheets and income statements for the sample of the research enterprises for the period (2011-2014), which has disclosed by the enterprises of the study sample.

\section{Study Instrument}

The data that have used in the study

The financial statements are for the period of 2008-2011 at the rate of four years each enterprise, where they were to rely on the financial statements of these enterprises, which are in the income statement and balance sheet, and statement of cash flows.

Statistical methods used in reaching the objectives of the study The purpose use a number of statistical methods are as follows:

A - Enter the financial statements on the Excel program to get the results of financial ratios, which represent the percentage of each of which is variable from the independent variables of the study.

B - The introduction of financial ratios that have extracted by the Excel program SPSS statistical software to measure the effect of the independent variables in the prediction of a stalled financial performance.

C - Statistical analysis of the data entered through the following tests:

- Analysis of the data on basis of multiple linear regression equation and using the method (Stepwise):

- Analysis discriminatory multivariate linear:

The analysis uses discriminatory linear multivariate to build a model consisting of a number of financial ratios. Through selecting the best financial ratios, and the most accurate in distinguishing, and predict the fail in industrial enterprises. It is also the selection of a set of ratios in the form of a linear equation through several steps, the most important test Wilks' Lambda, and checks the equal variance matrices for each group through the Box's M test, which gives the amount of level of statistical significance.

- Test Olap Cubes:

This test has used to make sure the independent variables undergo normal distribution

- Test Wilks' Lambda

It has known as the selection criterion by which it define. Is there a significant effect by the independent variables that we want to study? In addition, if the value is greater than the level of significance $(0.05)$ means that it is likely that 
there is no significant effect of the independent variables on the dependent variable. However, if value is smaller than the level of significance $(0.05)$ means that it is likely to have a significant effect of the independent variables on the dependent variable. This test has used to determine the best financial ratios in predicting a stalled financial performance of the industrial installations of the study sample.

- ANOVA test

It is an abbreviation for the term Analysis Of Variance This method relies on the so-called test $(\mathrm{F})$, which depends mainly on the analysis of the data, where the contrast is only the squares of deviations of the average values for the middle of the arithmetic.

If the number of independent variables is one variable, it called (One-Way Anova). If the numbers of independent variables have two, it has called (Two ways Anova). However, if the numbers of independent variables are more than two, as in this study has called, then analysis of variance $\mathrm{N}$ - way Anova.

\section{Statistical Results and Hypotheses testing}

This section aimed to analyze samples responses data and displaying the statistical results obtains to this study include hypothesis testing. It has been used of statistical methods to test hypotheses and build a mathematical model, we will give the results are as follows for the study.

\subsection{The first major hypothesis:}

Ho1: There is a positive effect statistically significant at the level of significance $(\alpha \leq 0.05)$ between financial ratios and predict of fail financial performance of industrial enterprises.

Regression equation has tested as follows:

$\mathbf{Y}=\mathbf{a}+\mathbf{b}_{1} \mathbf{X}_{1}+\mathbf{b}_{2} \mathbf{X}_{2}+\ldots \mathbf{b}_{30} \mathbf{X}_{30}$

These are:

(Y) Represents the dependent variable, the financial performance.

(a) Fixed value.

(b) The regression coefficient, which measures the amount of change in $\mathrm{Y}$ if $\mathrm{X}$ changed by one unit.

(X) Ratio calculated. 
Talal A. AL- Kassar/ Mourad Kouachi/ Ammar Nasruldeen Mohammed Sheet

Table (1) the results of analysis of variance to test the validity of the model

\begin{tabular}{|l|l|l|l|l|l|}
\hline $\begin{array}{l}\text { Source } \\
\text { of } \\
\text { variation }\end{array}$ & $\begin{array}{l}\text { Sum of } \\
\text { squares }\end{array}$ & $\begin{array}{l}\text { Degrees } \\
\text { of } \\
\text { freedom }\end{array}$ & $\begin{array}{l}\text { Squares } \\
\text { average }\end{array}$ & $\begin{array}{l}\text { Value of (F) } \\
\text { calculated }\end{array}$ & $\begin{array}{l}\text { Statistical } \\
\text { significance }\end{array}$ \\
\hline Regression & 1808754.282 & 30 & 60291.809 & 21734448.309 & $0.000^{*}$ \\
\hline Residual & 0.036 & 13 & 0.003 & & \\
\hline Overall & 1808754.318 & 43 & & & \\
\hline
\end{tabular}

* Impact statistically significant at the level of significance $(\alpha \leq 0.05)$.

It shown from table (1) above that there is an existence of the effect statistically significant at the level of significance $(\alpha \leq 0.05)$ for a number of independent variables (financial ratios) on the financial performance of the enterprises. The value of $(\mathrm{F})$ calculated $(21,734,448.309)$, the highest of value $(\mathrm{F})$ degrees of freedom when the spreadsheet $(30,13)$ which amounts to $(1.958)$. To test the impact of the financial ratios on the overall financial performance of the industrial enterprises sample of the study we will test multiple regression analysis and are as follows:

Table (2) the results ofmultiple regression analysisto testthe impact ofthe financial ratiosonthe financial performance

\begin{tabular}{|c|c|c|c|c|c|c|}
\hline $\begin{array}{l}\text { Independe } \\
\text { nt } \\
\text { variable }\end{array}$ & $\begin{array}{l}\text { Correlati } \\
\text { on } \\
\text { coefficie } \\
\mathrm{nt} \mathrm{R}\end{array}$ & $\begin{array}{l}\text { Interpretati } \\
\text { ve value } \mathrm{R} \\
2\end{array}$ & $\begin{array}{l}\text { Regressi } \\
\text { on } \\
\text { coefficie } \\
\text { nt }\end{array}$ & $\begin{array}{l}\text { Beta } \\
\text { coefficie } \\
\text { nt }\end{array}$ & Value (T) & $\begin{array}{l}\text { Significan } \\
\text { ce }\end{array}$ \\
\hline Constant & & & 0.249 & & 0.729 & 0.479 \\
\hline $\mathrm{X} 1$ & & & 0.009 & 0.000 & 0.085 & 0.934 \\
\hline $\mathrm{X} 2$ & & & -0.007 & 0.000 & -0.052 & 0.960 \\
\hline $\mathrm{X} 3$ & & & 0.155 & 0.000 & 0.940 & 0.365 \\
\hline $\mathrm{X} 4$ & & & 0.503 & 0.001 & 1.489 & 0.160 \\
\hline $\mathrm{X} 5$ & & & -0.008 & 0.000 & -0.711 & 0.490 \\
\hline X6 & & & 0.010 & 0.000 & 0.265 & 0.795 \\
\hline $\mathrm{X} 7$ & & & -0.233 & 0.000 & -0.377 & 0.712 \\
\hline $\mathrm{X} 8$ & & & 0.196 & 0.000 & 0.627 & 0.541 \\
\hline X9 & & & -0.009 & 0.000 & -0.918 & 0.375 \\
\hline $\mathrm{X} 10$ & & & 0.014 & 0.000 & 0.910 & 0.380 \\
\hline $\mathrm{X} 11$ & & & 0.002 & 0.000 & 1.450 & 0.171 \\
\hline $\mathrm{X} 12$ & & & -0.070 & 0.000 & -0.465 & 0.649 \\
\hline $\mathrm{X} 13$ & & & -0.012 & 0.000 & -0.217 & 0.831 \\
\hline
\end{tabular}


The role of financial analysis in evaluating the performance of industrial enterprises to predict financial failure

\begin{tabular}{|c|c|c|c|c|c|c|}
\hline $\mathrm{X} 14$ & \multirow{17}{*}{0.98} & \multirow{17}{*}{0.96} & -0.004 & -0.001 & -2.479 & $0.028^{*}$ \\
\hline $\mathrm{X} 15$ & & & -0.001 & 0.000 & -0.294 & 0.774 \\
\hline X16 & & & -0.080 & -0.001 & -2.420 & $0.031 *$ \\
\hline $\mathrm{X} 17$ & & & 0.079 & 0.000 & 1.667 & 0.119 \\
\hline X18 & & & 0.001 & 0.000 & 1.012 & 0.330 \\
\hline X19 & & & 0.000 & 0.000 & 0.058 & 0.955 \\
\hline $\mathrm{X} 20$ & & & 0.000 & 0.000 & 0.022 & 0.983 \\
\hline $\mathrm{X} 21$ & & & 0.000 & 0.000 & 0.246 & 0.810 \\
\hline $\mathrm{X} 22$ & & & -0.003 & -0.001 & -1.933 & 0.075 \\
\hline $\mathrm{X} 23$ & & & 0.010 & 0.001 & 0.354 & 0.729 \\
\hline $\mathrm{X} 24$ & & & 0.015 & 0.001 & 4.924 & $0.000^{*}$ \\
\hline $\mathrm{X} 25$ & & & 0.461 & 0.025 & 15.424 & $0.000 *$ \\
\hline $\mathrm{X} 26$ & & & -0.003 & 0.000 & -1.074 & 0.302 \\
\hline $\mathrm{X} 27$ & & & 0.000 & 0.000 & 0.769 & 0.456 \\
\hline $\mathrm{X} 28$ & & & -0.002 & -0.001 & -2.329 & $0.037^{*}$ \\
\hline $\mathrm{X} 29$ & & & 0.500 & 0.992 & $\begin{array}{l}12164.6 \\
74\end{array}$ & $0.000^{*}$ \\
\hline $\mathrm{X} 30$ & & & 0.002 & 0.000 & 0.392 & 0.702 \\
\hline
\end{tabular}

* Impact statistically significant at the level of significance $(\alpha \leq 0.05)$.

The results of multiple regression analysis showed that there is a statistically significant effect at the level of significance $(\alpha \leq 0.05)$ of the variables $(X 14$, $\mathrm{X} 16, \mathrm{X} 24, \mathrm{X} 25, \mathrm{X} 28, \mathrm{X} 29)$ to predict financial performance. Where the value of $(\mathrm{T})$ calculated a higher value $(\mathrm{T})$ when the spreadsheet degrees of freedom (43) and the level of significance (0.05) and adult (2.021), did not show the results of multiple regression analysis and the presence of a statistically significant effect for the rest of the variables are independent variables to predict financial performance. The results of the analysis show that the independent variables together explain $96 \%$ of the variance in predicting financial performance. The following chart illustrates the financial ratios of the impact on the financial performance: 
Figure (2) Regression coefficients for the financial ratios and its impact on the financial performance prediction

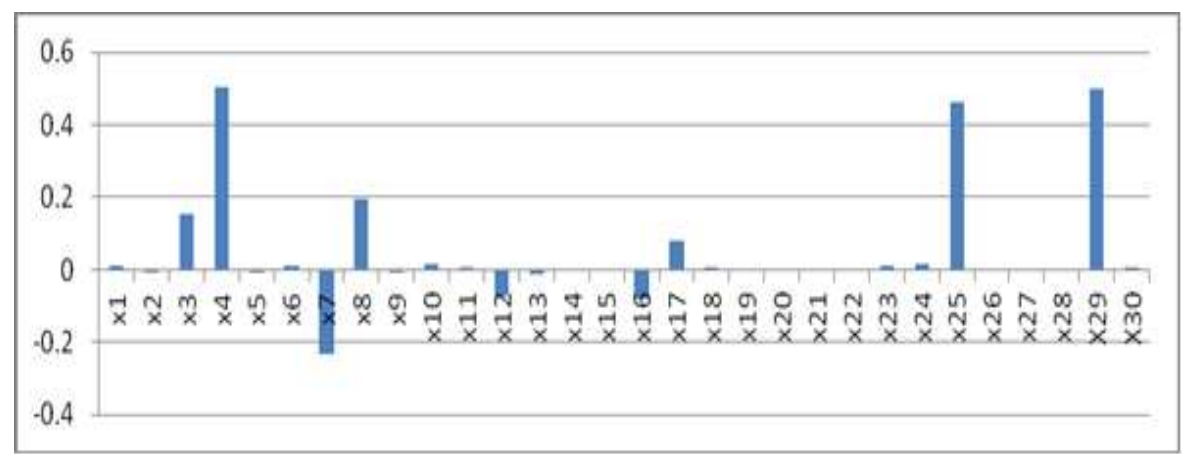

Thus, we accept the first major hypothesis H01: no statistically significant effect on the level of significance $(\alpha \leq 0.05)$ between financial ratios and predict a stalled financial performance.

The next table shows results of stepwise regression analysis that there are eight groups of financial ratios have significant explanatory ability of the dependent variable, which is the financial performance, was statistically significant (0.05). Table (3) will clarify the mathematical models.

The results of multiple regression analysis in the below table show that the existence of eight standard models (statistical) of the independent variables has an effect statistically significant at the level of significance

$(\alpha \leq 0.05)$ on the financial performance, and ranged ratios explanatory between $(87.8 \%)$ by fourth model and between $(93.5 \%)$ by the eighth form.

The variable (X 30), a ratio of capital to total debt income in the six models have had indications of strong statistical, and managed the first model that gives an indication of explanatory by $93.1 \%)$ ), a figure confirmed by the (Altman, 1968) in his study.

Table (3) results of multiple regression analysis to test the impact of financial ratios to predict financial performance

\begin{tabular}{|c|c|c|c|c|c|c|c|}
\hline $\begin{array}{l}\text { Group } \\
\mathrm{s}\end{array}$ & $\begin{array}{l}\text { Independe } \\
\mathrm{nt} \\
\text { variable }\end{array}$ & $\begin{array}{l}\text { Correlatio } \\
n \\
\text { coefficien } \\
t R\end{array}$ & $\begin{array}{l}\text { Interpretativ } \\
\text { e value } R^{2}\end{array}$ & $\begin{array}{l}\text { Regressio } \\
\mathrm{n} \\
\text { coefficien } \\
\mathrm{t}\end{array}$ & $\begin{array}{l}\text { Beta } \\
\text { coefficien } \\
\mathrm{t}\end{array}$ & Value (T) & $\begin{array}{l}\text { Significanc } \\
\mathrm{e}\end{array}$ \\
\hline \multirow{2}{*}{1} & Constant & \multirow{2}{*}{0.965} & \multirow{2}{*}{$93.1 \%$} & -0.415 & & -0.508 & 0.614 \\
\hline & $\mathbf{X}_{30}$ & & & 0.504 & 1.000 & 252.188 & 0.000* \\
\hline \multirow{2}{*}{2} & Constant & \multirow{2}{*}{0,960} & \multirow{2}{*}{$92.2 \%$} & -0.029 & & -1.358 & 0.182 \\
\hline & $\mathbf{X}_{30}$ & & & 0.500 & 0.992 & 9374.578 & 0.000* \\
\hline
\end{tabular}


The role of financial analysis in evaluating the performance of industrial enterprises to predict financial failure

\begin{tabular}{|c|c|c|c|c|c|c|c|}
\hline & $\mathbf{X}_{25}$ & & & 0.502 & \begin{tabular}{|l|}
0.027 \\
\end{tabular} & 252.942 & $0.000^{*}$ \\
\hline \multirow{4}{*}{3} & Constant & \multirow{4}{*}{0.942} & \multirow{4}{*}{$88.7 \%$} & -0.062 & & -3.974 & 0.000* \\
\hline & $X_{29}$ & & & 0.500 & 0.992 & $\begin{array}{l}12982.12 \\
3\end{array}$ & $0.000 *$ \\
\hline & $X_{25}$ & & & 0.488 & 0.026 & 188.030 & 0.000* \\
\hline & $X_{24}$ & & & 0.009 & \begin{tabular}{|l|l|}
0.001 \\
\end{tabular} & 6.510 & 0.000* \\
\hline \multirow{5}{*}{4} & Constant & \multirow{5}{*}{0.937} & \multirow{5}{*}{$87.8 \%$} & -0.136 & & -4.451 & $0.000^{*}$ \\
\hline & $\mathbf{X}_{30}$ & & & 0.500 & 0.992 & $\begin{array}{l}13205.64 \\
9\end{array}$ & $0.000 *$ \\
\hline & $\mathbf{X}_{25}$ & & & 0.487 & \begin{tabular}{|l|}
0.026 \\
\end{tabular} & 198.590 & $0.000^{*}$ \\
\hline & $\mathbf{X}_{24}$ & & & 0.010 & 0.001 & 7.086 & 0.000* \\
\hline & $\mathrm{X}_{8}$ & & & 0.162 & \begin{tabular}{|l|l|}
0.000 \\
\end{tabular} & 2.744 & $0.009^{*}$ \\
\hline \multirow{6}{*}{5} & Constant & \multirow{6}{*}{0.939} & \multirow{6}{*}{$88.2 \%$} & -0.129 & & -4.446 & 0.000* \\
\hline & $\mathbf{X}_{30}$ & & & 0.500 & 0.992 & $\begin{array}{l}13971.41 \\
0\end{array}$ & $0.000 *$ \\
\hline & $\mathbf{X}_{25}$ & & & 0.534 & \begin{tabular}{|l|}
0.028 \\
\end{tabular} & 27.370 & $0.000^{*}$ \\
\hline & $X_{24}$ & & & 0.011 & \begin{tabular}{|l|l|}
0.001 \\
\end{tabular} & 7.911 & 0.000* \\
\hline & $\mathbf{X}_{8}$ & & & 0.164 & 0.000 & 2.941 & 0.006* \\
\hline & $\mathbf{X}_{23}$ & & & $\begin{array}{l}-0.048 \\
\end{array}$ & -0.003 & -2.444 & 0.019* \\
\hline \multirow{7}{*}{6} & Constant & \multirow{7}{*}{0.957} & \multirow{7}{*}{$91.6 \%$} & -0.059 & & -1.677 & 0.102 \\
\hline & $\mathbf{X}_{30}$ & & & 0.500 & 0.992 & $\begin{array}{l}14993.07 \\
4\end{array}$ & $0.000 *$ \\
\hline & $\mathbf{X}_{25}$ & & & 0.543 & 0.029 & 30.062 & $0.000^{*}$ \\
\hline & $X_{24}$ & & & 0.010 & \begin{tabular}{|l|l|}
0.001 \\
\end{tabular} & 8.608 & $0.000 *$ \\
\hline & $\mathbf{X}_{8}$ & & & 0.178 & 0.000 & 3.498 & 0.001* \\
\hline & $\mathbf{X}_{23}$ & & & -0.060 & -0.003 & -3.295 & $0.002^{*}$ \\
\hline & $\mathrm{X}_{14}$ & & & -0.002 & \begin{tabular}{|l|l|}
0.000 \\
\end{tabular} & -2.945 & 0.006* \\
\hline \multirow{8}{*}{7} & Constant & \multirow{8}{*}{0.964} & \multirow{8}{*}{$92.9 \%$} & -0.009 & & -0.212 & 0.833 \\
\hline & $\mathrm{X}_{29}$ & & & 0.500 & 0.992 & $\begin{array}{l}15622.49 \\
7\end{array}$ & $0.000^{*}$ \\
\hline & $\mathbf{X}_{25}$ & & & 0.536 & 0.029 & 30.705 & 0.000* \\
\hline & $\mathbf{X}_{24}$ & & & 0.010 & \begin{tabular}{|l|}
0.001 \\
\end{tabular} & 9.064 & 0.000* \\
\hline & $\mathbf{X}_{8}$ & & & 0.155 & \begin{tabular}{|l|l|}
0.000 \\
\end{tabular} & 3.154 & 0.003* \\
\hline & $\mathbf{X}_{23}$ & & & -0.054 & -0.003 & -3.043 & 0.004* \\
\hline & $X_{14}$ & & & -0.002 & 0.000 & -3.296 & 0.002* \\
\hline & $\mathbf{X}_{13}$ & & & $\begin{array}{l}-0.018 \\
\end{array}$ & \begin{tabular}{|l|l|}
0.000 \\
\end{tabular} & -2.296 & $0.028^{*}$ \\
\hline \multirow{8}{*}{8} & Constant & \multirow{8}{*}{0.967} & \multirow{8}{*}{$93.5 \%$} & 0.039 & & 0.941 & 0.353 \\
\hline & $\mathrm{X}_{\mathbf{3 0}}$ & & & 0.500 & 0.992 & $\begin{array}{l}16346.71 \\
8\end{array}$ & $0.000^{*}$ \\
\hline & $\mathbf{X}_{25}$ & & & 0.517 & \begin{tabular}{|l|}
0.028 \\
\end{tabular} & 29.401 & $0.000^{*}$ \\
\hline & $X_{24}$ & & & 0.011 & \begin{tabular}{|l|}
0.001 \\
\end{tabular} & 9.939 & $0.000^{*}$ \\
\hline & $\mathbf{X}_{8}$ & & & 0.279 & 0.000 & 4.327 & 0.000* \\
\hline & $X_{23}$ & & & -0.035 & -0.002 & -2.017 & 0.051* \\
\hline & $\mathrm{X}_{14}$ & & & -0.002 & 0.000 & -4.429 & 0.000* \\
\hline & $\mathrm{X}_{13}$ & & & -0.023 & 0.000 & -3.062 & 0.004* \\
\hline
\end{tabular}


Talal A. AL- Kassar/ Mourad Kouachi/ Ammar Nasruldeen Mohammed Sheet

\begin{tabular}{|l|l|l|l|l|l|l|l|}
\hline & $\mathrm{X}_{16}$ & & & -0.034 & $\mathbf{0 . 0 0 0}$ & $-\mathbf{2 . 7 0 2}$ & $\mathbf{0 . 0 1 1 *}$ \\
\hline
\end{tabular}

* Impact statistically significant at the level of significance $(\alpha \leq 0.05)$.

5.1.1 Test results of the first sub-hypothesis

H01a: no statistically significant effect at the level of significance $(\alpha \leq 0.05)$ between liquidity ratios and predict a stalled financial performance.

Hypothesis has tested by entering a set of variables liquidity ratios (X1 - X8) to gain access to the financial ratios with the greatest impact on financial performance as follows:

Table (4) the results of multiple regression analysis to test impact of liquidity ratios to predict financial performance

\begin{tabular}{|c|c|c|c|c|c|c|c|c|}
\hline $\begin{array}{l}\text { Independ } \\
\text { ent } \\
\text { variable }\end{array}$ & $\begin{array}{l}\text { Correlat } \\
\text { ion } \\
\text { coeffici } \\
\text { ent } \mathrm{R}\end{array}$ & $\begin{array}{l}\text { Interpreta } \\
\text { tive } \\
\text { value } \mathrm{R}^{2}\end{array}$ & $\begin{array}{l}\text { F } \\
\text { Valu } \\
\text { e }\end{array}$ & $\begin{array}{l}\text { Signific } \\
\text { ance }\end{array}$ & $\begin{array}{l}\text { Regressi } \\
\text { on } \\
\text { coefficie } \\
\text { nt }\end{array}$ & $\begin{array}{l}\text { Beta } \\
\text { coeffi } \\
\text { cient }\end{array}$ & $\begin{array}{l}\text { Value } \\
\text { (T) }\end{array}$ & $\begin{array}{l}\text { Significa } \\
\text { nce }\end{array}$ \\
\hline Constant & \multirow{9}{*}{0.482} & \multirow{9}{*}{$23.2 \%$} & \multirow{9}{*}{2.023} & \multirow{9}{*}{$0.042^{*}$} & 197.676 & & 1.878 & 0.068 \\
\hline $\mathrm{X}_{1}$ & & & & & -81.136 & -0.569 & -0.826 & 0.414 \\
\hline $\mathrm{X}_{2}$ & & & & & 117.838 & 0.590 & 0.841 & 0.405 \\
\hline $\mathrm{X}_{3}$ & & & & & 104.356 & 0.129 & 0.696 & 0.491 \\
\hline $\mathrm{X}_{4}$ & & & & & 157.728 & 0.205 & 0.972 & 0.337 \\
\hline $\mathrm{X}_{5}$ & & & & & 2.111 & 0.036 & 0.229 & 0.820 \\
\hline $\mathrm{X}_{6}$ & & & & & -3.462 & -0.077 & -0.523 & 0.604 \\
\hline $\mathrm{X}_{7}$ & & & & & -16.075 & -0.017 & -0.093 & 0.926 \\
\hline $\mathrm{X}_{8}$ & & & & & -507.984 & -0.522 & -2.424 & $0.020^{*}$ \\
\hline
\end{tabular}

* Impact statistically significant at the level of significance $(\alpha \leq 0.05)$.

The results of multiple regression analysis and the existence of the effect statistically significant at the level of significance $(\alpha \leq 0.05)$ only when the variable (X8) of variables liquidity ratios eight to predict financial performance, where the value of (T) calculated (2.424) and statistical significance to it is $(0.020)$. The regression results show that the liquidity ratios combined explain for the eight ratios is $(23.2 \%)$ of the variation of financial performance. Thus, the first sub hypothesis is accepted.

\subsubsection{Test results of the second sub-hypothesis}


The role of financial analysis in evaluating the performance of industrial enterprises to predict financial failure

$\mathrm{Ho}_{1} \mathrm{~b}$ : There is a positive effect statistically significant at the level of significance $(\alpha \leq 0.05)$ between activity ratios and predict of fail financial performanceof industrial enterprises.

Table (5) the results of multiple regression analysis to test impact of the activity ratios to predict financial performance

\begin{tabular}{|c|c|c|c|c|c|c|c|c|}
\hline $\begin{array}{l}\text { Indepen } \\
\text { dent } \\
\text { variable }\end{array}$ & $\begin{array}{l}\text { Correla } \\
\text { tion } \\
\text { coeffici } \\
\text { ent } \mathrm{R}\end{array}$ & $\begin{array}{l}\text { Interpr } \\
\text { etative } \\
\text { value } \\
\mathrm{R}^{2} \\
\end{array}$ & $\begin{array}{l}\text { F } \\
\text { Valu } \\
\text { e }\end{array}$ & $\begin{array}{l}\text { Signific } \\
\text { ance }\end{array}$ & $\begin{array}{l}\text { Regres } \\
\text { sion } \\
\text { coeffic } \\
\text { ient } \\
\end{array}$ & $\begin{array}{l}\text { Beta } \\
\text { coeffi } \\
\text { cient }\end{array}$ & $\begin{array}{l}\text { Value } \\
(\mathrm{T})\end{array}$ & $\begin{array}{l}\text { Signifi } \\
\text { cance }\end{array}$ \\
\hline $\begin{array}{l}\text { Constan } \\
\mathrm{t}\end{array}$ & \multirow{6}{*}{0.158} & \multirow{6}{*}{$2.5 \%$} & \multirow{6}{*}{0.194} & \multirow{6}{*}{$0.963 *$} & -64.847 & & -0.898 & 0.375 \\
\hline $\mathrm{X}_{9}$ & & & & & 4.328 & 0.080 & 0.365 & 0.717 \\
\hline $\mathrm{X}_{10}$ & & & & & 1.881 & 0.048 & 0.256 & 0.800 \\
\hline$X_{11}$ & & & & & -0.137 & -0.016 & -0.101 & 0.920 \\
\hline $\mathrm{X}_{12}$ & & & & & -33.847 & -0.082 & -0.407 & 0.686 \\
\hline$X_{13}$ & & & & & 17.411 & 0.131 & 0.586 & 0.561 \\
\hline
\end{tabular}

* Impact statistically significant at the level of significance $(\alpha \leq 0.05)$.

The results of multiple regression analysis the lack of effect statistically significant at the level of significance $(\alpha \leq 0.05)$ for any of the ratios of activity to predict financial performance. Where the values of $(\mathrm{T})$ calculated less than the value of $(\mathrm{T})$ critical show that the rates of activity of the five combined ratios explain $(2.5 \%)$ of the variation of financial performance. Although the highest among the group had an impact on the financial performance is variable (X11), a ratio of sales to working capital have reached statistical significance (0.920). Thus, we reject the hypothesis of sub-second, and accept the alternative hypothesis, which says:

- No effect is statistically significant at the level of significance $(\alpha \leq 0.05)$ between activity ratios and predict of fail financial performance.

5.1.3 Test results of the third sub-hypothesis

$\mathrm{Ho}_{1} \mathrm{c}$ : There is a positive effect statistically significant at the level of significance $(\alpha \leq 0.05)$ between the solvency and predict of fail financial performance of industrial enterprises.

Table (6) the results of multiple regression analysis to test impact of solvency ratios to predict financial performance 
Talal A. AL- Kassar/ Mourad Kouachi/ Ammar Nasruldeen Mohammed Sheet

\begin{tabular}{|c|c|c|c|c|c|c|c|c|}
\hline $\begin{array}{l}\text { Independ } \\
\text { ent } \\
\text { variable }\end{array}$ & $\begin{array}{l}\text { Correlat } \\
\text { ion } \\
\text { coeffici } \\
\text { ent R }\end{array}$ & $\begin{array}{l}\text { Interpr } \\
\text { etative } \\
\text { value R } \\
2\end{array}$ & $\begin{array}{l}\mathrm{F} \\
\text { Value }\end{array}$ & $\begin{array}{l}\text { Signific } \\
\text { ance }\end{array}$ & $\begin{array}{l}\text { Regressi } \\
\text { on } \\
\text { coefficie } \\
\text { nt }\end{array}$ & $\begin{array}{l}\text { Beta } \\
\text { coeffi } \\
\text { cient }\end{array}$ & $\begin{array}{l}\text { Value } \\
\text { (T) }\end{array}$ & $\begin{array}{l}\text { Significa } \\
\text { nce }\end{array}$ \\
\hline Constant & \multirow{7}{*}{0.484} & \multirow{7}{*}{$23.4 \%$} & \multirow{7}{*}{2.088} & \multirow{7}{*}{$0.039 *$} & 68.835 & & 0.503 & 0.617 \\
\hline $\mathrm{X}_{14}$ & & & & & -0.494 & -0.065 & -0.306 & 0.761 \\
\hline $\mathrm{X}_{15}$ & & & & & 0.417 & 0.068 & 0.325 & 0.747 \\
\hline $\mathrm{X}_{16}$ & & & & & 2.281 & 0.229 & 1.423 & 0.162 \\
\hline $\mathrm{X}_{17}$ & & & & & -13.537 & -0.038 & -0.273 & 0.786 \\
\hline $\mathrm{X}_{18}$ & & & & & -0.116 & -0.019 & -0.137 & 0.892 \\
\hline $\mathrm{X}_{19}$ & & & & & -3.808 & -0.298 & -2.087 & $0.048^{*}$ \\
\hline
\end{tabular}

* Impact statistically significant at the level of significance $(\alpha \leq 0.05)$.

The results of multiple regression analysis show an effect of significant at the level of significance $(\alpha \leq 0.05)$ of the variable (X19) of debt ratios on financial performance. Which is the proportion of debtors to revenue, where the value of (T) calculated is higher than value (T) at the critical degree of freedom (43) and the level of significance (0.05) and reached (2.021). Results of the analysis did not show the presence of the impact for the rest of solvency ratios to predict financial performance. The regression results show that all solvency ratios indicators combined explain (23.4\%) of the variation of financial performance. Thus, accept the third sub-hypothesis.

\subsubsection{Test results of the fourth sub-hypothesis}

$\mathrm{Ho}_{1} \mathrm{~d}$ : There is a positive effect statistically significant at the level of significance $(\alpha \leq 0.05)$ between profitability ratios and predict of fail financial performanceof industrial enterprises.

Table (7) the results of multiple regression analysis to test impact of profitability ratios to predict financial performance

\begin{tabular}{|c|c|c|c|c|c|c|c|c|}
\hline $\begin{array}{l}\text { Independ } \\
\text { ent } \\
\text { variable }\end{array}$ & $\begin{array}{l}\text { Correlat } \\
\text { ion } \\
\text { coeffici } \\
\text { ent } \mathrm{R}\end{array}$ & $\begin{array}{l}\text { Interpreta } \\
\text { tive value } \\
\mathrm{R}^{2}\end{array}$ & $\begin{array}{l}\text { F } \\
\text { Valu } \\
\text { e }\end{array}$ & $\begin{array}{l}\text { Signific } \\
\text { ance }\end{array}$ & $\begin{array}{l}\text { Regress } \\
\text { ion } \\
\text { coeffici } \\
\text { ent }\end{array}$ & $\begin{array}{l}\text { Beta } \\
\text { coeffi } \\
\text { cient }\end{array}$ & $\begin{array}{l}\text { Value } \\
\text { (T) }\end{array}$ & $\begin{array}{l}\text { Significa } \\
\text { nce }\end{array}$ \\
\hline $\begin{array}{l}\text { Constan } \\
\text { t }\end{array}$ & \multirow{9}{*}{0.711} & \multirow{9}{*}{$50.6 \%$} & \multirow{9}{*}{3.793} & \multirow{9}{*}{$0.001 *$} & -42.248 & & -0.898 & 0.375 \\
\hline $\mathbf{X}_{20}$ & & & & & -0.455 & -0.049 & -0.227 & 0.822 \\
\hline $\mathbf{X}_{21}$ & & & & & -0.192 & -0.142 & -0.990 & 0.328 \\
\hline$X_{22}$ & & & & & 1.008 & 0.678 & 4.060 & $0.000 *$ \\
\hline$X_{23}$ & & & & & -42.750 & -1.743 & -0.863 & 0.394 \\
\hline$X_{24}$ & & & & & 0.542 & 0.039 & 0.137 & 0.892 \\
\hline $\mathrm{X}_{25}$ & & & & & 51.355 & 2.042 & 1.048 & 0.302 \\
\hline$X_{26}$ & & & & & 0.669 & 0.027 & 0.227 & 0.822 \\
\hline $\mathbf{X}_{27}$ & & & & & 0.533 & 0.171 & 1.267 & 0.213 \\
\hline
\end{tabular}


The role of financial analysis in evaluating the performance of industrial enterprises to predict financial failure

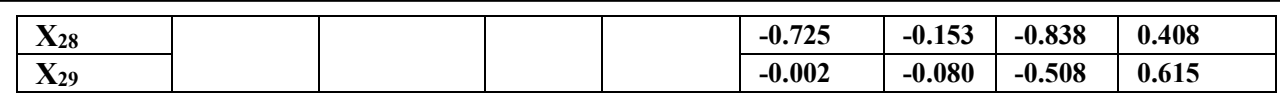

* Impact statistically significant at the level of significance $(\alpha \leq 0.05)$.

The results of multiple regression analysis show an effect of significant at the level of $(\alpha \leq 0.05)$ of the variable (X22) of profitability ratios on financial performance. Which is the ratio of net profit before tax to current liabilities, where the value of $(\mathrm{T})$ calculated is higher than value $(\mathrm{T})$ at the critical degree of freedom (43) and the level of significance (0.05) which was (2.021). The regression results show that profitability of all ten ratios has collectively explained $(50.6 \%)$ of the variation financial performance, thus accept the forth sub-hypothesis.

5.1.5 Test results of the fifth sub-hypothesis

$\mathrm{Ho}_{1} \mathrm{e}$ : There is a positive effect statistically significant at the level of significance $(\alpha \leq 0.05)$ between market rates and predict of fail financial performanceof industrial enterprises.

Table (8) the results of multiple regression analysis to test impact of market ratio to predict financial performance

\begin{tabular}{|l|l|l|l|l|l|l|l|c|}
\hline $\begin{array}{l}\text { Indepen } \\
\text { dent } \\
\text { variable }\end{array}$ & $\begin{array}{l}\text { Correla } \\
\text { tion } \\
\text { coeffici } \\
\text { ent R }\end{array}$ & $\begin{array}{l}\text { Interpr } \\
\text { etative } \\
\text { value } \\
\mathrm{R}^{2}\end{array}$ & F Value & $\begin{array}{l}\text { Signif } \\
\text { icance }\end{array}$ & $\begin{array}{l}\text { Regre } \\
\text { ssion } \\
\text { coeffi } \\
\text { cient }\end{array}$ & $\begin{array}{l}\text { Beta } \\
\text { coeffi } \\
\text { cient }\end{array}$ & $\begin{array}{l}\text { Value } \\
(\mathrm{T})\end{array}$ & $\begin{array}{l}\text { Signific } \\
\text { ance }\end{array}$ \\
\cline { 1 - 5 } $\begin{array}{l}\text { Consta } \\
\text { nt }\end{array}$ & $\mathbf{1 . 0 0 0}$ & $\mathbf{1 0 0 \%}$ & $\mathbf{1 2 4 5 9 8 . 8 6}$ & $\mathbf{0 . 0 0 0 *}$ & $\mathbf{- 0 . 5 2 0}$ & & $\mathbf{- 0 . 7 0 2}$ & $\mathbf{0 . 4 8 6}$ \\
\cline { 1 - 5 } & & & & & $\mathbf{0 . 5 0 3}$ & $\mathbf{1 . 0 0 0}$ & $\mathbf{3 5 2 . 9 8 5}$ & $\mathbf{0 . 0 0 0 *}$ \\
\hline
\end{tabular}

*Impact statistically significant at the level of significance $(\alpha \leq 0.05)$.

The results of the analysis of simple regression to the existence of the effect statistically significant at the level of significance $(\alpha \leq 0.05)$ of the variable (X30), which is a ratio of capital to total debt to predict financial performance. Where the value of $(\mathrm{T})$ calculated is higher than value of $(\mathrm{T})$ critical when the degree of freedom (43) and the level of significance (0.05) and was (2.021). The regression results show that the ratio of capital to total debt explains $(100 \%)$ of the variation of the financial performance, thus accept the fifth subhypothesis.

\subsection{The second major hypothesis:}

$\mathrm{Ho}_{2}$ : distinguishes quantitative predictive model consisting of a set of financial ratios, which will reached by using the statistical method accurately between successful industrial enterprises and distressed.

In order to prove or deny this hypothesis. It was to follow a number of statistical methods to arrive at the implications of a strong and reliable, and that the method used in this study - to reach the model- is the analysis method discriminatory and which is used in the prediction or classification in areas 
where the dependent variable qualitatively, such as distressed and nondistressed.

The first step: to ensure undergo independent variables (financial ratios) used in the study of the normal distribution, mean and others.

The second step: making sure there is equal variance matrices, one of the steps of analysis to test the discriminatory "Box's M", which is to make sure the matrices of equal variance or not.

The third step: For testing whether there are differences between the dependent variable, and the independent variables, we tested the possibility of the existence of differences using analysis of variance (ANOVA), to know the function of discrimination, which consists of a number of financial variables.

The fourth step: to get to the discrimination linear function equation, we have extracted the parameters of this function, using the Stepwise method which gives us the results of the most important variables of financial transactions with linear, where each variable of variables extracted coefficient discrimination.

The fifth step: to test the equation on a group of successful enterprises and failed.

Therefore, extract from the table below category estimated coefficient functions, and both functions can be used to classify of enterprises sample in one of the two groups, where we re-estimate values by these functions, and then re-rating in the group that have the greatest value.

Table (9) Estimated classification functions coefficients

\begin{tabular}{|c|c|c|}
\hline \multicolumn{3}{|c|}{ classification } \\
\hline Independentvariable & Success & Failed \\
\hline$X_{30}$ & .000 & $4.109 E-006$ \\
\hline$X_{25}$ & .416 & -1.729 \\
\hline$X_{21}$ & -.001 & .028 \\
\hline$X_{19}$ & .004 & .459 \\
\hline Constant & -1.943 & -11.183 \\
\hline
\end{tabular}

So (X30) was excluded out of the equation, where the coefficient equal to $(0.00)$ in the classification of successful enterprises, which are close to zero in the classification of non-performing enterprises, according to the table above. Therefore, the function of successful enterprises as follows: $\mathrm{D} 1=0.416 * \mathrm{X} 25-0.001 * \mathrm{X} 21+0.004 * \mathrm{X} 19-1.943$

In addition, the functions of the failed enterprises are as follows: 
$\mathrm{D} 2=-1.720 * \mathrm{X} 25+0.028 * \mathrm{X} 21+0.459 * \mathrm{X} 19-11.183$

\section{Results and Recommendations:}

Through the study of financial analysis and statistical for food Industrial enterprises in Jordan, shows the importance of the role-played by the financial statements in providing accurate and honest. In addition, the truth about the financial performance, away from bias, beautify the image of the financial statements through the methods of creative accounting and others. The importance of the role played by those lists to get the information that predicts the financial performance of the industrial enterprises and the role of financial analysis, forecasting and its importance in a failed financial performance of enterprises across multiple ways and means. Among the most important results of the financial analysis, which has reached this study are:

Build a modelconsisting ofa set ofpercentageof finance, whichhaveeachone of themweighingweighted, which reflects its importancein distinguishingbetweensuccessful enterprisesandfailed, as well as the impact offinancial ratiosto predictfinancial performance, which helps totake appropriate action toavoidfinancial distressbefore it happens. The model has applied to reclassification of food enterprises. The result has shown that fully and accurately by (100\%). Moreover, was able to distinguish between successful and non-performing enterprises. The study showed that it does not need many financial ratios to be able to predict a stalled financial performance of the enterprise is likely, and that with the progress of statistical analysis methods remains discriminatory analysis statistical tool is very effective and reliable.

Based on the results of the study lead researcher with the following recommendations:

1 The study recommends using the form of enterprises and the stock market for the early detection of faltering financial performance of food enterprises, and the rest of other industrial enterprises, to avoid exposure of those enterprises to financial failure.

2 The study recommends the need to update the form by researchers or by the departments of enterprises, to ensure continuity, and effectiveness, and until there is an accurate and objective in this model to predict the correct classification.

3 The study recommends using the form by the industrial enterprises, by classify enterprises that could handle and assess its performance, to identify strengths and weaknesses, and work to overcome the weakness to raise the level of performance of the enterprise towards success.

\section{References}


Abdel-Kader, M., and Luther, R., 2008. The impact of firm characteristics on management accounting practice: a UK-based empirical analysis. The British Accounting Review, 40(1), 2-27.

Abdel-Maksoud, A., Cerbioni, F., Ricceri, F., and Velayutham, S., 2010. Employee morale, non-financial performance measures deployment of innovative managerial practices and shop-floor involvement in Italian manufacturing firms. The British Accounting Review, 42 (1), 36-55.

Al-Khalayla, Mahmoud, (2012), financial analysis using financial statements, Amman - Jordan, Dar Wael for publication pp.3-42.

Al-Kassar, T., and Soileau, J., 2012, Design and Applied Mathematical Model of Measuring Financial Performance Evaluation: Jordan Results, Oil, Gas \& Energy Quarterly, 60 (3) 621-636.

Al-Kassar, T., and Soileau, J., (2014), Design Financial performance evaluation and bankruptcy prediction (failure), Arab Economics and Business Journal, 9 (2) 147-155.

Al-Nu'aimi, Adnan, and Al-Tamimi, Ershaid (2008), Financial Analysis and Planning, Contemporary Trends, Jordan - Amman, Dar Yazori for Publication and Distribution.

Altman, E. I., 1968, Financial Ratios Discriminant Analysis and the Prediction of Corporate Bankruptcy, Journal of Finance, 23 (4) 589-609.

Belkaoui, A., and AlNajjar, F. (2006), Earnings opacity internationally and elements of social, economic and accounting order. Review of Accounting and Finance, 3 (3), 130-144.

Bemmann, Martin, Improving the Comparability of Insolvency Predictions (June 23, 2005).Dresden Economics Discussion Paper Series No. 08/2005. Available at:http://ssrn.com/abstract $=731644$.

Chenhall, R. H. (2006). The contingent design of performance measures. In Bhimani (Ed.), Contemporary issues in management accounting (pp. 92-116). Oxford: Oxford University Press.

Karajeh, Abdul Halim and Rababa'a, Ali and Sekran Yasser, Matar Moses and Joseph, Tawfiq, (2006), Management and Financial Analysis (Principles, Concepts, Applications), $2^{\text {nd }}$ edition, Jordan - Amman, Dar Safa'a. pp. 156-157.

Khanfar, M, \& Mattarneh, Ghassan, (2011), Financial statements Analysis, Theoretical and Practical Approach, 3rd ed., Amman - Jordan, Dar Al Masira for publication and distribution.

Miller, W. (2009), Introducing the Morningstar Solvency Score, A

Bankruptcy PredictionMetric, Morningstar, Inc. December 2009, Electronic copy available at:http://ssrn.com/abstract=1516762.

Munuswamy, Dr. Shanmugam‘ Dr. Zulkifflee Bin Mohamed, (2012),

Evaluating Company Failure In Malaysia Using Financial Ratios 
The role of financial analysis in evaluating the performance of industrial enterprises to predict financial failure

And Logistic Regression, Asian Journal Of Finance \& Accounting, Vol. 4, No 1.

Taffler, R. J., 1983, The Z-Score Approach to Measuring Company Solvency, the Accountant's Magazine, March, 22-24.

\section{Websites :}

Accounting program banks, stock exchanges,"accounting tools to support decisions of the stock market", (http://bu.edu.eg) on 02/4/2015.

Site - Jordan Chamber of Industry, (http://www.jci.org.jo) on 09/4/2015.

Appendix 1 Financial ratios and the extent of the study sample used in previous studies

Code Description ratio measuring the ratio

X1 Liquidity Ratio

X2 Quick ratio

$\mathrm{X} 3 \quad$ cash ratio

X4 working capital to total assets

X5 working capital to sales

X6 cash flow to total liabilities

$\mathrm{X} 7 \quad$ cash to sales ratio

$\mathrm{X} 8 \quad$ current assets to total assets

X9 Inventory Turnover $=$ Net sales to inventory activity

$\mathrm{X} 10$

debtor's turnover ratio of sales to debtor's

liquidity

liquidity

liquidity

liquidity

liquidity

liquidity

liquidity

X11 turnover of working capital to sales ratio = working capital

activity

activity

asset turnover ratio of sales to assets

$\mathrm{X} 12$

Turnover $=$ ratio of current assets to current assets sales

activity

activity

Debt Ratio $=$ Total Liabilities to Total Assets

solvency

Ownership=Total liabilities to owners equity

solvency

X16 financing fixed assets ratio $=($ owner equity + long-term

liabilities) / Total fixed assets solvency

X17 inventory to owner equity

solvency

receivables to total debt

solvency

$\begin{array}{ll}\text { X19 } & \text { debtors to sales } \\ \text { X20 net profit to sales }\end{array}$

$\mathrm{X} 21$

profit before interest and tax to sales

profitability

solvency net profit before tax to current liabilities profitability net profit before interest and tax to total assets profitability net profit before tax to invested capital profitability return on assets ratio $=$ net profit after tax to total assets profitability $\mathrm{ROE}=$ ratio of net profit to owners equity profitability retained earnings to total assets profitability net profit to the number of shares of profitability 